\title{
ASSESSMENT OF BED JOINTS BEHAVIOR OF CALCIUM SILICATE BRICK MASONRY DURING EXECUTION
}

\author{
Tomas ŠLIVINSKAS ${ }^{\mathrm{a}}$, Bronius JONAITIS ${ }^{\mathrm{b}}$, Łukasz DROBIEC ${ }^{\mathrm{c}}$ \\ ${ }^{a, b}$ Vilnius Gediminas Technical University, Sauletekio al. 11, LT-10223 Vilnius, Lithuania \\ 'Politechnika Slaska, Akademicka 5, 44-100 Gliwice, Poland
}

Received 12 September 2016; accepted 16 September 2016

\begin{abstract}
This article examines masonry as the composite material. Factors affecting the mechanical deformation characteristics of masonry bed joints are reviewed. The strength and deformation characteristics of bed joints under the influence of changing mortar strength and variable compressive load are analysed Compressive strength, shrinkage and plastic deformation of masonry fragments and bed joints under variable compressive strength are also examined.
\end{abstract}

Keywords: masonry, mortar, bed joint deformation, water absorption, variable compressive strength.

\section{Introduction}

In order to evaluate the tension, compressive strength and deformations of masonry structures it is necessary to assess more accurately the deformation characteristics of masonry.

For the examination of the mechanical properties of masonry as a composite material numerous micro and macro simulations of masonry behavior are applied. By carrying out the computer micro or macro simulations it is particularly important to have actual mechanical characteristics of masonry.

Mechanical characteristics of masonry, including deformations, depend on many factors: ability of masonry mortar to give back water, water absorption of masonry unit's, ambient temperature, humidity, quality of work, etc. (Huster 2000; Zavalis, Jonaitis 2011).

According to the literature review it is clear that in many cases the masonry deformations are determined by the deformation of bed joints, i.e. by the deformation of mortar joints and the contact zone (Zavalis, Jonaitis 2011).

Many authors investigate (Huster 2000; Derluyn et al. 2008) mechanical properties of masonry, as well as the deformations of mortar in bed joints, when masonry mortar reaches its designed strength. However, under real-life conditions the compressive stress in bed joints occurs and increases gradually. This is caused by the weight load of constructions being built. In this case, the mortar hardens under different conditions compared to the unloaded masonry. The contact zone between mortar bed joints and masonry units are changing (Janssen 2007, 2012).

The construction of masonry buildings is complex, it consists of several closely related jobs. Frequently the constructions of masonry buildings are divided into sections, where the workers during one shift would construct a single height masonry wall. In this way of construction the load affecting the constructed masonry walls gradually increases from the first days before masonry mortar reaches the designed strength. During construction the load changes, the mortar in bed joints is gradually affected by the increasing pressure, which is caused by the weight of masonry walls being built and ceilings being mounted. The mortar in bed joints is compacted by this pressure additionally. The degree of compaction depends on the rheological character-

Corresponding author:

Ł.Drobiec E-mail: lukasz.drobiec@polsl.pl 
istics of mortar. While analysing literature the authors haven't found any comprehensive studies on behavior of masonry and bed joints in a changeable situation, i.e. during the construction stages.

The article examines the behavior of mortar and change of its mechanical characteristics due to variable load. It was accepted that the duration of the changeable situation are 34 days. This duration tallies with the point at which the masonry reaches its design strength. The research results of behaviour of masonry and bed joints which are affected by compressive load during the changeable situation are discussed.

\section{Factors affecting the deformation characteristics of the masonry bed joints}

The bed joints have a significant impact on masonry mechanical characteristics. The main factors affecting the characteristics of mortar bed joints can be divided into two groups - the interaction of mortar and masonry units and the mortar hardening conditions at bed joint (Zavalis et al. 2014).

The masonry units absorb water from the mortar after the mortar bed joint is formed. The absorption of water depends on the masonry structure (the amount of pores and capillary absorption rate) and mortar characteristics to give back water. Depending on the composition of mortar and the ratio of water and cement, the mortar at the bed joint loses about $40-60 \%$ of moisture (water) (Ince et al. 2009).

The thickness of mortar layer from which the clay masonry unit absorbs water is up to $5 \mathrm{~mm}$ (Ince et al. 2009). It can be assumed that if the thickness of bed joint is $10-12 \mathrm{~mm}$, the masonry units absorb water from both surfaces of masonry bed joints over the entire thickness of the bed joint. According to research (Derluyn et al. 2011), the ratio of the cement mortar water and the cement reduces from 0.5 to 0.35 , i.e. up to $30 \%$.

At a certain depth, the masonry unit pores accumulate absorbed water. When the water amount in mortar decreases (i.e. the ratio of the water and cement decreases) there is a possibility that the mortar strength of the middle layer of mortar will increase. According to the research of the characteristics of cement mortar after the ratio of water and cement decreases, the mortar strength increases (Nagaraj, Shashiprakash 1996).

The water from the mortar bed joint is absorbed within a very short time period, in approximately 20 seconds (Ince et al. 2009), therefore the mortar at bed joint becomes stiffer, the different density zones appear, which leads to uneven distribution of compressive stresses at joints. The research (Brocken et al. 1998) shows that because of such a rapid water absorption a good contact between mortar bed joint and masonry units form in only about $20-30 \%$ of the surface area of contact.

On the other hand, from the first the mortar in the bed joint is affected by the compressive loads. It leads to the additional release of water (water is squeezed out from the mortar). The density of mortar increases because of the impact of compressive stress, the mortar hardens affected by the complex stress state. The layer forms in the contact, the strength and elasticity module of which are significantly different from the mortar characteristics at the inner layers which were defined in the tests according to the methods specified in standard EN 1015-11 (Huster 2000; Zavalis, Jonaitis 2011; Derluyn et al. 2008).

Longitudinal deformations of contact zones which represent a large proportion of all mortar bed joints' deformations form because of the roughness and the stress concentration. For this reason, the bed joint deformations under the same stress are significantly different from the deformations of mortar, which were defined in tests of the standard mortar specimen.

\section{The programme of experimental research}

The target of experimental research is the $125 \times 88 \times 250 \mathrm{~mm}$ silicate brick fragments - specimen. The height of specimen is $500 \mathrm{~mm}$. The masonry fragments are bricklayed without a cross joint, the thickness of bed joint is $12 \mathrm{~mm}$ (Fig. 1).

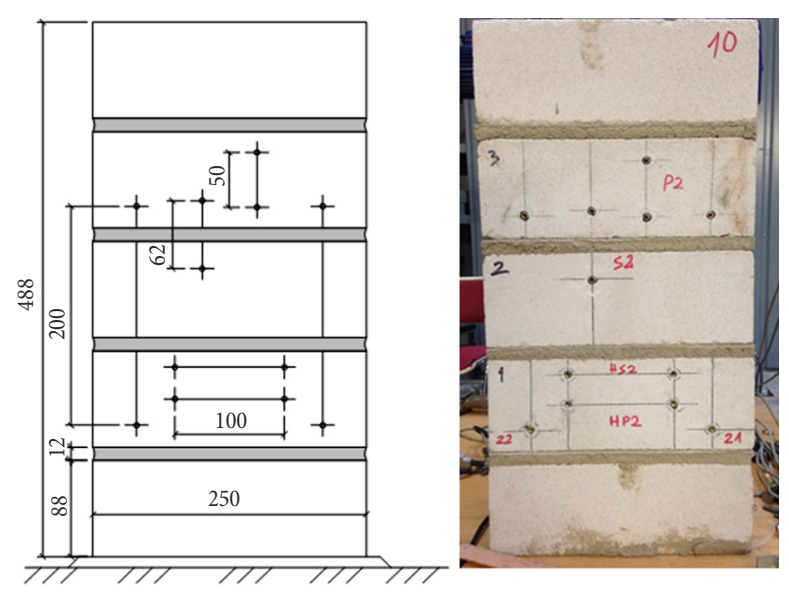

Fig. 1. Masonry fragment composed of $5250 \times 125 \times 88 \mathrm{~mm}$ silicate bricks and of 11-12 mm thickness cement mortar bed joints 
The average compressive strength of masonry unit is $32 \mathrm{~N} / \mathrm{mm}^{2}$. The capillary absorption rate of silicate bricks is not determined according to standards. However, according to the authors' opinion, this phenomenon affects the water absorption of silicate units. The average capillary water absorption rate of bricks $-1.45 \mathrm{~kg} /\left(\mathrm{m}^{2} \cdot \mathrm{min}\right)$. Silicate masonry unit capillary absorption rate is determined according to the standard LST EN 722-11 by using the methodology of determination of ceramic masonry units' capillary absorption.

The cement mortar was used for the bricklaying of brick specimen. The composition ratio of cement mortar was 1:4 (cement: sand). The quartz sand was used. Its texture was up to $2 \mathrm{~mm}$, the cement - Portland cement. The ratio of water and cement was $\mathrm{v} / \mathrm{c}=1.05$, the mortar mobility movements according to the cone penetration test $-7 \mathrm{~cm}$.

The compressive strength of cement mortar was determined while testing standard specimen according to LST EN 1015 standards. An elasticity modulus of mortar was determined while testing specimens with dimensions of $40 \times 40 \times 160 \mathrm{~mm}$.

A series of 6 specimens - masony fragments were produced to carry out the experiment investigation. The specimen of B1-B5 series were tested with a short-term static load after the 1, 2, 7, 14 and 34 days of hardening. After 1 day, the specimens of B6 series were loaded with gradually increasing load. The intensity of load was increased gradually every seven days and maintained for 34 days. The lever was used for loading (Fig. 2), which provides a constant load in each stage.

The variation of compressive stress is presented in Figure 3. The load intensity and its variations from the day 1 to the day 34 conform to the variation of stress at masonry wall when the weight of built constructions is increased. Such load intensity and its variation conforms to the increase in load of masonry wall during the first month of the construction (Fig. 3). The first and the third stages correspond to the load increase while bricklaying the walls in the ground and the first floors. The second and the fourth stages correspond to the load increase because of assembling ceiling slabs and weight of technical equipment.

Masonry fragments (Series B6) were affected with a progressively increasing static load and after 34 days were unloaded and tested with a short-term static load. At the same time (after 34 days) the not loaded specimens were tested as well (Series B5).
During the test shrinkage deformations of the masonry bed joints were measured, the deformations of masonry, masonry units, and bed joints that were loaded with the progressively increasing compressive load, and also their variations were determined. Moreover, the changes of relative humidity were also observed (Fig. 4). The ambient temperature throughout the whole test period was constant $18{ }^{\circ} \mathrm{C}$, the temperature fluctuations were $\pm 1{ }^{\circ} \mathrm{C}$.

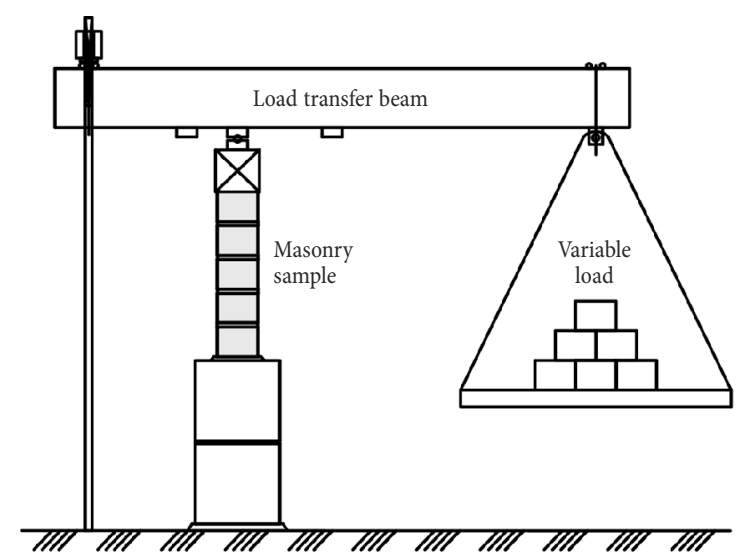

Fig. 2. The scheme of specimen that are loaded with a changing in time load

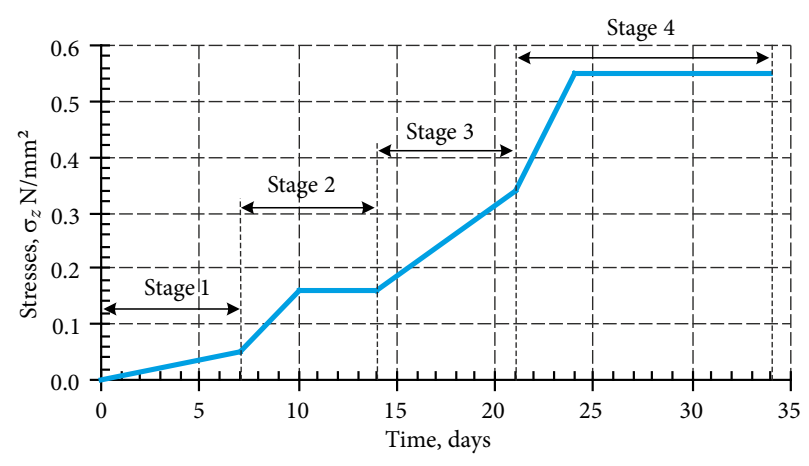

Fig. 3. The variation of s4tress at masonry wall with the increasing weight of built constructions

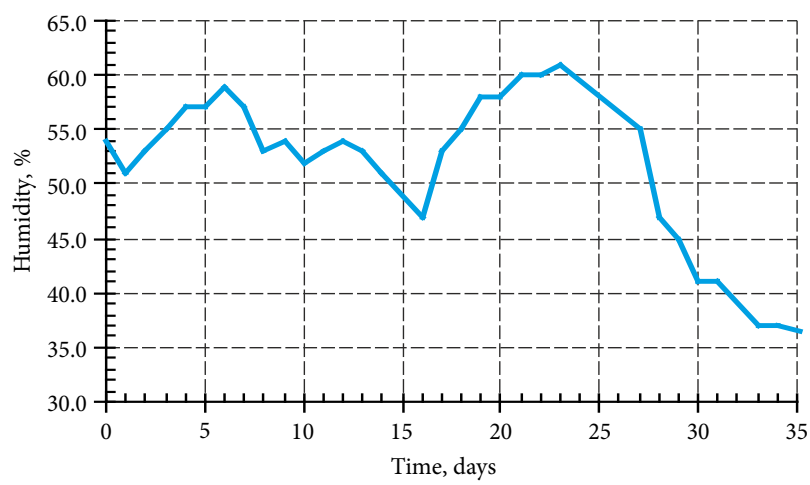

Fig. 4. The schedule of ambient relative humidity change 
While testing specimens that were not affected by short-term static load and those, which were affected by the load of changing intensity, the deformations of masonry units, masonry, and bed joints were measured as well.

The bed joint mortar plates were taken from specimens of Series B6 and the mortar compressive strength and its variation in the joint were tested while performing a double punch test.

\section{Research results}

While bricklaying the specimens, the depth of silicate brick water absorption at bed joint were recorded. An average depth of brick water absorption was about $9 \mathrm{~mm}$ (Fig. 5).

When the joint had formed after 1 hour the mortar was taken out and the bricks were weighted, and it was found that the bricks absorbed approximately $70 \mathrm{ml}$ of water out of one mortar bed joint. After the absorbtion of water from the mortar joint, the ratio of water and cement decreased up to $90 \%$ and was equal to approximately 0.1 . For this reason, the mortar becomes stiff and it affects the contacts' formation between joint and masonry unit.

During the research, the shrinkage of masonry mortar units and mortar in bed joints were measured. The measurements started after 1 day after formation of specimens. The research results are presented in Figures 6-8.

The diagrams (Fig. 6) show that mortar's shrinkage is significantly higher than the deformations of masonry units. The shrinkage deformation of mortar intensively develops during the first 15 days, and then the shrinkage rate decreases. The variation of inclusive deformations of both masonry units and mortar correlates with the variation of relative humidity. The humidity changes are shown in Figure 4.

The shrinkage of masonry and bed joints started to be measured immediately after the formation of masonry specimens (Figs 7, 8).

The graph (Fig. 7) shows that when at the initial stage the masonry units adsorb water from the bed joints, the masonry mortar fragments start swelling. Meanwhile the bed joint mortar rapidly shrinks (Fig. 8). Later, when the masonry units release the humidity to the environment and to the mortar at bed joint, the masonry begins to shrink.

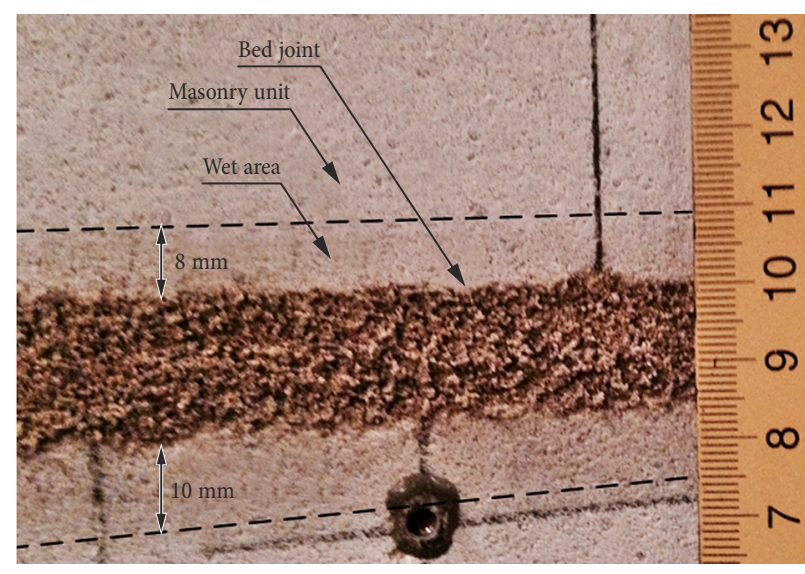

Fig. 5. Silicate brick water absorption depth at masonry mortar bed joints

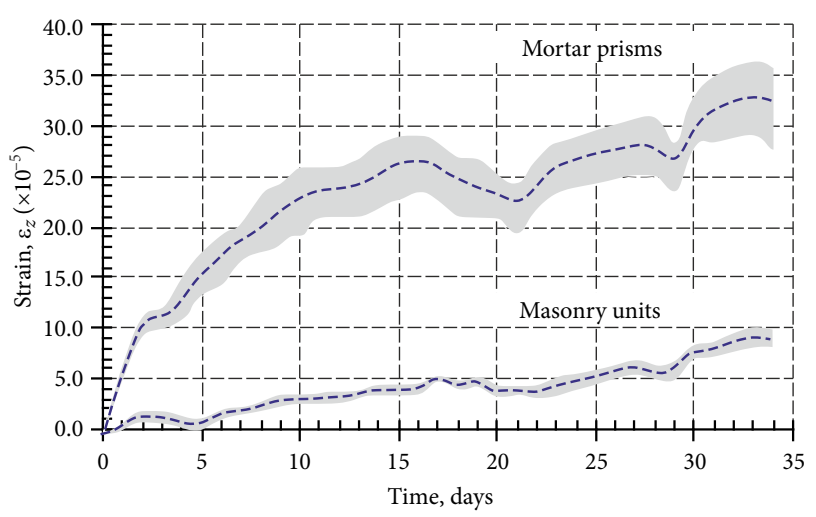

Fig. 6. The shrinkage of masonry units and mortar prisms (mortar specimens)

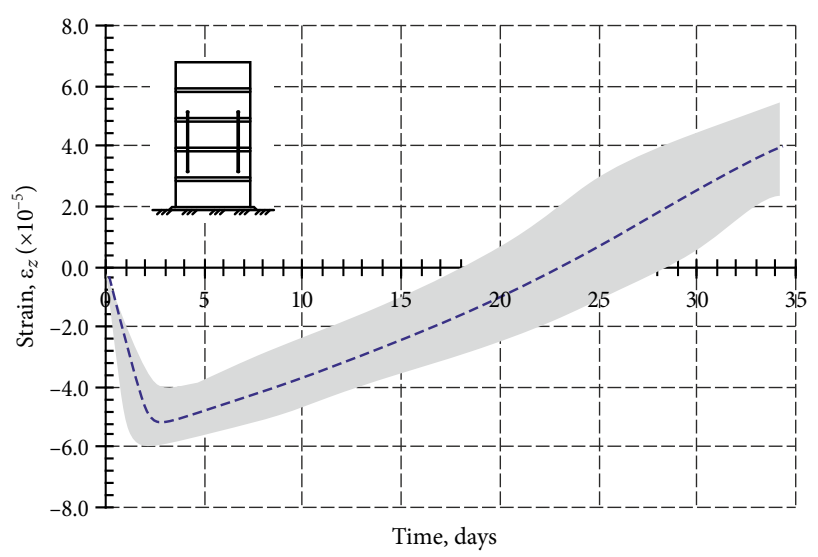

Fig. 7. The relative average shrinkage deformations of masonry specimens

The changes during the time of deformations of masonry fragments that are loaded with load of variable intensity have shown that the plastic deformations (creep) of masonry and mortar bed joints appear (Figs 9-11) when the load is maintained in constant levels (Fig. 9). 


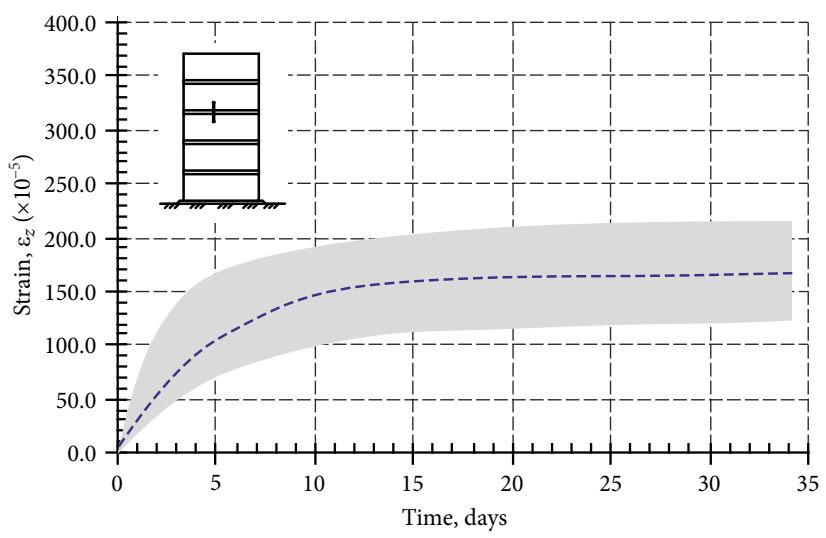

Fig. 8 . The relative average shrinkage deformations of masonry mortar in bed joint

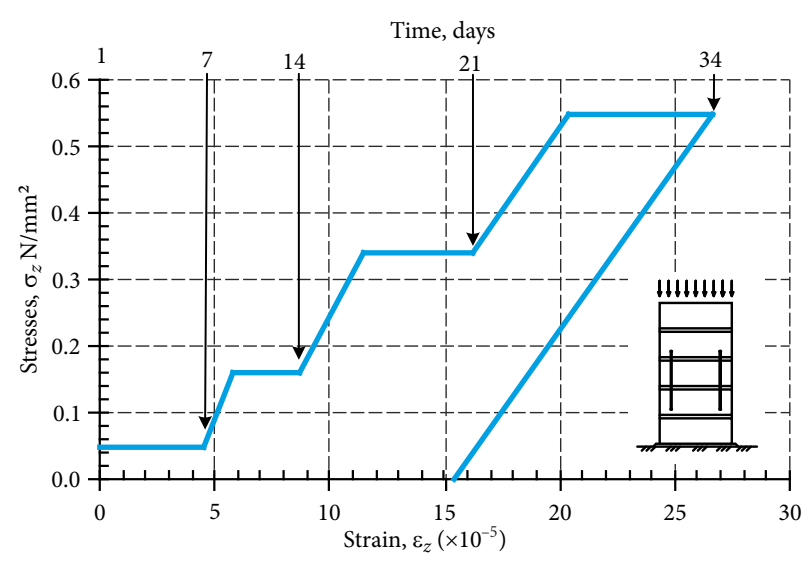

Fig. 9. The relative longitudinal plastic deformations of masonry fragment compressed with the changing load over the time

The plastic deformations intensively increase under the influence of the long-term load of changing intensity. The greater part of these deformations consists of deformations of mortar bed joints. The masonry plastic deformations are determined by the plastic deformations of bed joints. When the load is removed after 34 days, part of the deformations has recovered (Figs 10, 11). Total amount of deformation includes approximately $55 \%$ of the residual masonry deformations.

The compressive strength of masonry, the changing of masonry and bed joints deformations and masonry elastic modulus was set after testing the masonry fragments (Series B1-B6) with the short-term static load. The test results are presented in Table 1 and graphs (Figs 12-15).

34 days of compression with the load of changing intensity have no influence on masonry compressive strength. The compressive strength of compressed masonry in comparison with the uncompressed masonry after 34 days has increased by only 1.5\% (Table 1).

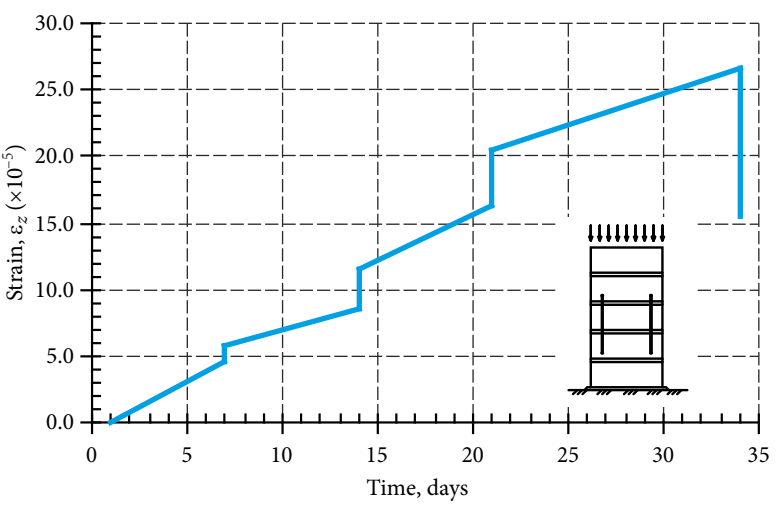

Fig. 10. The dependence of the relative longitudinal deformations of masonry fragment compressed with the changing load over the time

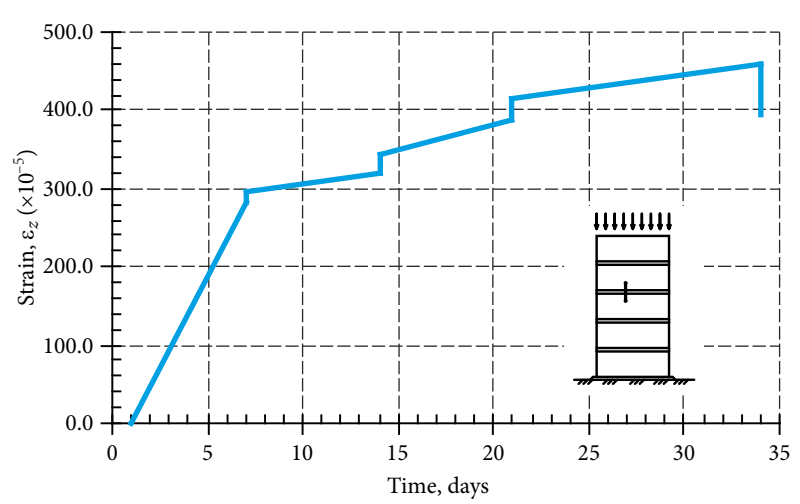

Fig. 11. The dependence of the relative longitudinal deformations of bed joint of masonry fragment compressed with the changing load over the time

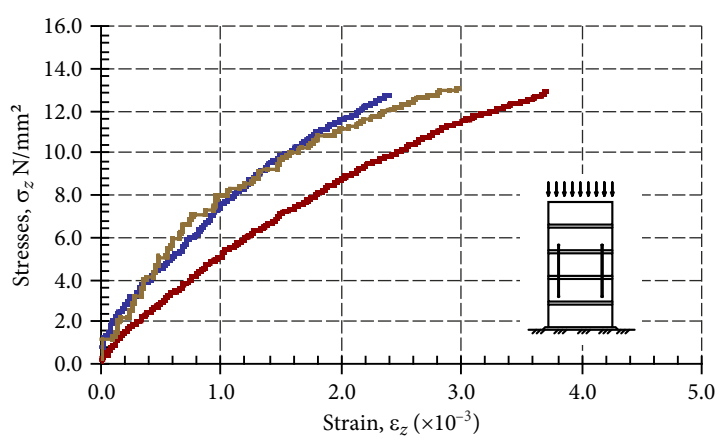

Fig. 12. The dependence of the Serial B6 masonry specimens stress under the short-term load

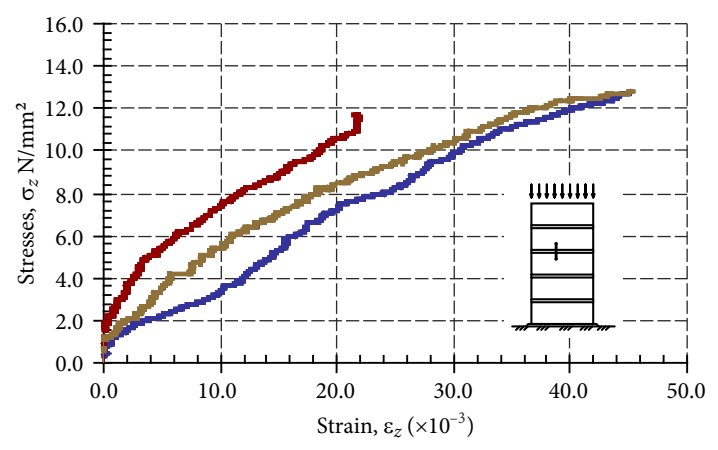

Fig. 13. The dependence of the Serial B6 masonry specimens of bed joint stress under the short-term load 
Table 1. The samples parameters and test results

\begin{tabular}{|c|c|c|c|c|c|}
\hline $\begin{array}{c}\text { Serial } \\
\text { number }\end{array}$ & $\begin{array}{c}\text { Age of } \\
\text { specimen } \\
\text { in days }\end{array}$ & $\begin{array}{c}\text { Compressive strength } \\
\text { of masonry speciments, } \\
\mathrm{N} / \mathrm{mm}^{2} \\
\text { (Variation coef.) }\end{array}$ & $\begin{array}{c}\text { Elastic modulus } \\
\text { of masonry } \\
\mathrm{E}_{\mathrm{cm}} \mathrm{N} / \mathrm{mm}^{2} \times 10^{-3} \\
\text { (Variation coef.) }\end{array}$ & $\begin{array}{c}\text { Compressive strength } \\
\text { of masonry mortar, } \\
\mathrm{N} / \mathrm{mm}^{2} \\
\text { (Variation coef.) }\end{array}$ & $\begin{array}{c}\text { Elastic modulus } \\
\text { of masonry mortar } \\
\mathrm{E}_{\mathrm{cm}} / \mathrm{mm}^{2} \times 10^{-3} \\
(\text { Variation coef.) }\end{array}$ \\
\hline B 1 & 1 & 11.08 & 6.76 & - & $1.95(7.47)$ \\
\hline B 2 & 2 & $10.99(2.82)$ & $7.52(32.84)$ & $7.26(5.68)$ & $3.74(3.25)$ \\
\hline B 3 & 7 & $12.13(3.68)$ & $9.30(6.79)$ & $6.40(11.08)$ & $8.45(12.63)$ \\
\hline B 4 & 14 & $12.56(2.41)$ & $8.24(11.42)$ & $6.78(9.46)$ & $8.36(14.38)$ \\
\hline B 5 & 34 & $13.26(1.14)$ & $9.16(7.94)$ & $7.75(15.60)$ & $8.16)$ \\
\hline B 6 & 34 & $13.46(4.02)$ & $9.16(6.53)$ & $10.36)$ \\
\hline
\end{tabular}

Note: ${ }^{*}$ Tested samples after unloading were influenced by the variable load. The intensity load is presented in Figure 3.

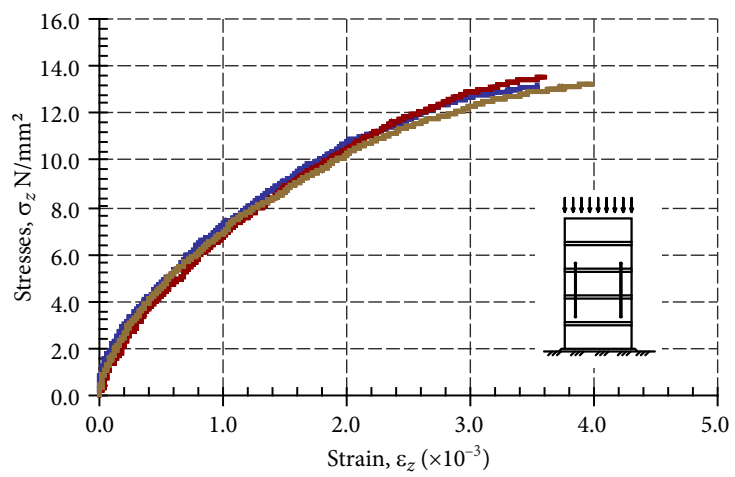

Fig. 14. The dependence of the Serial B5 masonry specimens stress under the short-term load

The test results of deformations of compressive masonry and mortar bed joints have shown that in all cases longitudinal deformations of bed joints are significantly higher and the deformations of the compressive masonry are determined (Figs 12-15).

The masonry compression with the load of changing intensity for 34 days from the begining of the bricklaying had no effect on longitudinal deformations of both masonry and bed joints (Figs 12-15).

The initial masonry compressive strength (after 1 day of hardening) was quite big and led to these results. Stifness of mortar joints has significantly increased because of the decrease of water and cement ratio when the bricks absorbed from mortar. On the other hand, the variation of mounted loads which corresponded the own weight of two-storey wall and ceiling accordingly caused the compression of slight intensity.

\section{Conclusions}

The shrinkage deformations of mortar specimens develop intensively during the first 10-15 days, after this the development of them stabilizes and varies slightly (Fig. 6).

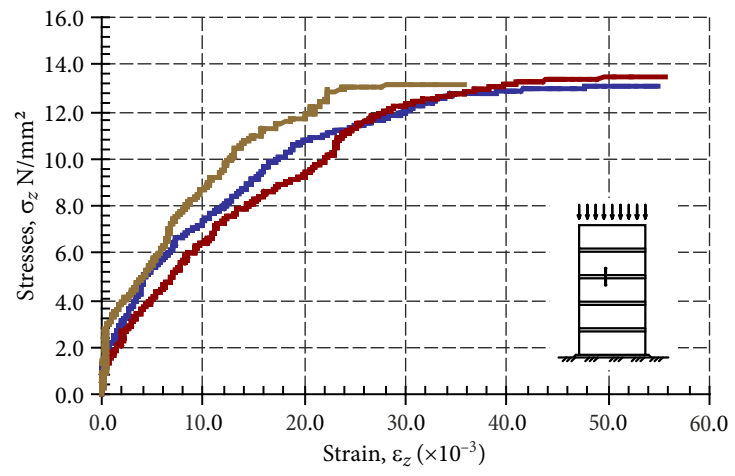

Fig. 15. The dependence of the Serial B5 masonry specimens of bed joint stress under the short-term load

During the first 1-3 days swelling deformations of formed masonry specimens develop, which are determinated by water absorption of masonry unit (Fig. 7).

The longitudinal plastic deformation occurs at masonry fragments that are loaded with the variable load and when among the loadings is acting fixed-medium stress (Figs 10, 11). The major part of the vertical deformation consists of mortar bed joints deformation (Fig. 11).

When the stiff cement mortar without plasticizers was used, the loading during a variable time by the compression load didn't have an influence on compressive strength until the mortar has reached the design strength.

\section{References}

Brocken, H. J. P.; Spiekman, M. E.; Pel, L.; Kopinga, K.; Larbi, J. A. 1998. Water extraction out of mortar during brick lying: A NMR study, Materials and Structures 31: 49-57. https://doi.org/10.1007/BF02486414

Derluyn, H.; Janssen, H.; Carmeliet, J. 2008. Moisture transfer across the interface between brick and mortar joint, Proceedings of the Nordic Symposium on Building Physics 2: 865-872.

Derluyn, H.; Janssen, H.; Carmeliet, J. 2011. Influence of the nature of interfaces on the capillary transport in layered ma- 
terians, Construction and Building Materials 25: 3685-3693. https://doi.org/10.1016/j.conbuildmat.2011.03.063

EN 1015-11:2004 Methods of test for mortar for masonary Part 11: Determination of flexural and compressive strength of hardened mortar.

EN 722-11:2011 Methods of test for masonry units - Part 11: Water absorption of aggregate concrete, autoclaved aerated concrete masonry units due to capillary action.

Huster, U. 2000. Tragverhalten von einschaligem Natursteinmauerwerk unter zentrischer Druckbeanspruchung. Kassel: Kassel University Press.

Ince, C.; Carter, M. A.; Wilson, M. A.; El-Turki, A.; Ball, R. J.; Allen, G. C.; Collier, N. C. 2009. Analysis of the abstraction of water from freshly mixed jointing mortars in masonry construction, Materials and Structures 43: 985-992. https://doi.org/10.1617/s11527-009-9560-5
Janssen, H.; Derluyn, H.; Carmeliet, J. 2007. Moisture transfer through mortar joints: interface resistances or hygric property changes?, in Proceedings of the $12^{\text {th }}$ Symposium for Building Physics, 29-31 March 2007, Dresden, Germany.

Janssen, H.; Derluyn, H.; Carmeliet, J. 2012. Moisture transfer through mortar joints: a sharp-front analysis, Cement and Concrete Research 42: 1105-1112.

https://doi.org/10.1016/j.cemconres.2012.05.004

Nagaraj, T. S.; Shashiprakash, S. G. 1996. Generalized Abrams' law, Properties of Fresh Concrete 216-224.

Zavalis, R.; Jonaitis, B. 2011. Mūro gaminių ir gulsčiųjų siūlių ịtempių deformacijų būvio ypatumų analizè, Engineering Structures and Technologies 3: 105-111.

Zavalis, R.; Jonaitis, B.; Lourenco, P. B. 2014. Analysis of bed joint influence on masonry modulus of elasticity, in $9^{\text {th }} \mathrm{In}$ ternational Masonry Conference, 7-9 July 2014, Guimarães, Portugal. 